\title{
Coleopteran Pollinators of Annonaceae in the Brazilian Cerrado-A Review
}

\author{
Fábio Pinheiro Saravy ${ }^{1}$, Marinez Isaac Marques ${ }^{1,2}$ and Karl-L. Schuchmann 1,2,3,*(D) \\ 1 Postgraduate Program in Zoology, Institute of Biosciences, Federal University of Mato Grosso (UFMT), \\ Fernando Correa da Costa Av. 2367, Cuiabá 78060-900, MT, Brazil; biofazoologia@gmail.com (F.P.S.); \\ marinez@ufmt.br (M.I.M.) \\ 2 Computational Bioacoustics Research Unit (CO.BRA), National Institute for Science and Technology in \\ Wetlands (INAU), Federal University of Mato Grosso (UFMT), Fernando Correa da Costa Av. 2367, \\ Cuiabá 78060-900, MT, Brazil \\ 3 Zoological Research Museum A. Koenig (ZFMK), Ornithology, Adenauerallee 160, 53113 Bonn, Germany \\ * Correspondence: klschuchmann@googlemail.com
}

Citation: Saravy, F.P.; Marques, M.I.; Schuchmann, K.-L. Coleopteran Pollinators of Annonaceae in the Brazilian Cerrado-A Review. Diversity 2021, 13, 438. https:// doi.org/10.3390/d13090438

Academic Editor: Luc Legal

Received: 16 August 2021

Accepted: 8 September 2021

Published: 10 September 2021

Publisher's Note: MDPI stays neutral with regard to jurisdictional claims in published maps and institutional affiliations.

Copyright: (c) 2021 by the authors. Licensee MDPI, Basel, Switzerland. This article is an open access article distributed under the terms and conditions of the Creative Commons Attribution (CC BY) license (https:// creativecommons.org/licenses/by/ $4.0 /)$.

\begin{abstract}
The evolutionary trajectories of insects and angiosperms appear to be intimately interconnected. Increases in the diversity of phytophagous beetles and angiosperms co-occur in the Mesozoic fossil record, and there is fossil evidence of pollinivory and pollination by insects, both in flowering plants and in gymnosperms. The oldest records of angiosperm pollination indicate flies as pollen vectors. A basal group of angiosperms, the order Magnoliales, has retained plesiomorphic characters such as dozens of pistils and stamens spiraling around the receptacle. In a family of this order, Annonaceae, over 90\% of species are pollinated by beetles. In many Annonaceae species, flowers display wide spaces, referred to as floral chambers, where beetles can find shelter from weather conditions and predators, food in the form of pollen and tissues, and a mating site. Two basic types of floral chambers can be distinguished: small chambers visited by small beetles (Nitidulidae, Staphylinidae, Chrysomelidae, and Curculionidae) with diurnal and/or nocturnal activity and large and thermogenic floral chambers visited by beetles of the tribe Cyclocephalini (Scarabaeoidea, Melolonthidae). In the latter case, the heat that the flowers produce may serve as a resource for the beetles that visit them, resulting in smaller endothermy costs for the scarabs. This study reviewed the literature including PhD and MSc theses on cantharophilous Annonaceae in the Cerrado. In this biome, both types of associations are found, although cantharophilous Annonaceae represent a small portion of the plant species $(<5 \%)$. Cantharophilous Annonaceae in the Cerrado share attributes according to the beetles that pollinate them: species pollinated by small beetles, for instance, may flower throughout the year, whereas Annonaceae pollinated by Cyclocephalini normally flower in the beginning of the rainy season (October/November), in synchrony with the phenological patterns of their pollinators. Cantharophilous Annonaceae flowers, regardless of their size, tend to have light colors and sweet and fruity odors. In addition to the lack of studies on the attraction of beetles by these floral characters, the taxonomic composition of the beetles that pollinate Annonaceae in the Cerrado is poorly known. This review attempts to discuss, in light of what has already been published, potential fields of investigation concerning pollinating beetles' behavior and evolution.
\end{abstract}

Keywords: Annonaceae; Cerrado; Cyclocephalini; Nitidulidae; pollination; Staphylinidae

\section{Introduction}

After the survival of one or two lineages during the mass extinction event at the end of the Permian ( 253 MYA), there was accentuated diversification in the Coleoptera (Arthropoda, Hexapoda, Insecta) during the Mesozoic, generally attributed to the concomitant diversification of angiosperms [1-4]. The major characteristics of insects in general were already established by the Late Cretaceous [5], and four great lineages of Polyphaga (Tenebrionoidea, Scarabaeoidea, Curculionoidea, and Chrysomeloidea) currently associated 
with angiosperms had already diversified, according to both fossil records and molecular evidence [6]. Fossil records of pollinivory in beetles from the Buprestidae and Scraptiidae date back to the early Cenozoic [5].

In the early Cenomanian, approximately 100 MYA, lowlands were dominated by angiosperms including magnoliids [5]. It is estimated that Annonaceae, within the clade of basal angiosperms Magnoliidae, diverged at least 108.6 MYA [7]. Annonaceae, similar to plants from other families in the Magnoliales, show basal flower characteristics (e.g., numerous stamens spiraling around many pistils, a superior ovary, sessile stamens, and apocarpy) [8-10].

Unlike the remaining basal angiosperms, which currently include at most a few hundred relict species, Annonaceae underwent greater ecological radiation and wider diversification [11]. With a pantropical distribution, the family includes approximately 2430 species in 110 genera. In Brazil, 400 species in 29 genera occur $[9,12]$.

The floral biology of modern Annonaceae results from the combination of basal characters and relatively recent floral specializations derived from a high diversification rate such as the circadian trapping of floral visitors $[8,13]$. Another distinguishing characteristic of Annonaceae is that they are mostly pollinated by beetles [14].

The syndrome of pollination by beetles, also denominated cantharophily [15], occurs in various angiosperm families in addition to Annonaceae such as Araceae [16-20], Arecaceae [21-24], Cyclanthaceae [16,25-28], Magnoliaceae [29-32], and Orchidaceae [33-35].

This pollination syndrome might be even older, tracing back to the Late Cretaceous, with staphylinid fossils covered in gymnosperm pollen, suggesting a possibly more remote origin of cantharophily before the establishment and dominance of angiosperms in terrestrial ecosystems [5]. Extant gymnosperms in the genera Cycas L., Zamia L., and Encephalartos Lehm. are pollinated by beetles, especially Curculionidae and Nitidulidae, in an interaction frequently referred to as brood pollination [24,36-40]. The nitidulid Carpophilus chalybeus Murray feeds on and breeds in both female and male cones of Cycas revoluta Thunb., damaging some of its sporophylls. Nevertheless, even the cones most damaged by beetles do not show seed set below $30 \%$. On the Japanese island of Yonaguni, this Cycadaceae species may be pollinated by nitidulids of the species Carpophilus chalybeus as well as by wind. The latter facilitates pollination in plant populations densely clustered in an area, whereas beetles promote pollen transfer to female cones of more distant individuals [39]. This pollination system, in which both biotic and abiotic factors are involved, is termed ambophily [41].

In Arecaceae (palms), plants whose fossil records indicate a Cretaceous origin, the body of literature of the XIX century and early XX century points to generalized anemophily [42]. With advances in studies of taxa from this family, floral specializations such as thermogenesis have been discovered. Currently, one of the most favored hypotheses claims that palms evolved from a more generalized entomophilous system to an ambophilous one in which wind and more specialized groups of insects such as weevils and nitidulid beetles contributed to pollination [21,41-43]. Diverging hypotheses state that entomophily (pollination by insects) is the ancestral condition in angiosperms and that anemophily (wind pollination) is derived [41,43].

A change in this paradigm was proposed in a recent study that dated angiosperm radiation to the late Triassic, which may have profound implications for the evolution of pollination biology not only in this group of plants, but also in gymnosperms [44,45]. Taking these data into account, in the context of the Mesozoic, in which both gymnosperms and basal angiosperms coexisted, two scenarios are possible: angiosperms evolved from insect-pollinated gymnosperms, co-opting the insects, or, in the case of a more likely Triassic origin of angiosperms, the opposite might have occurred (i.e., gymnosperms co-opted insects that pollinated angiosperms) [44,45].

In the clade ANITA (Amborellaceae, Nymphaeales, and Austrobaileyales), which includes the most basal angiosperms and sister to all other flowering plants, the most frequent pollination syndrome is myophily (fly pollination); the second most common syndrome is 
cantharophily. Hence, it is estimated that fly pollination is the oldest specialization among entomophilous flowers [46]. Pollen clumping dates date back to the Middle Cretaceous and indicates an increase in the occurrence of zoophily, when the existence of flies with mouth parts adapted to pollinivory was already present in the fossil record [47]. Paccini and Hesse (2005) [48] also mentioned the abundant setae in fossil Diptera that would facilitate the adhesion of pollen clumps, which could act together with sticky substances from pollen grains such as pollenkitt.

Still, within the ANITA clade, although the order of aquatic plants Nymphaeales is mostly pollinated by bees, a specialized type of pollination is promoted by beetles in the genera Victoria Lindl., Nymphaea L., and Nuphar Sm. The Nymphaea species that present diurnal anthesis are pollinated by bees and flies, whereas species with nocturnal anthesis are pollinated by beetles. In addition to nocturnal anthesis, cantharophilous species of Nymphaeaceae also possess other characteristics in common: they are thermogenic and have complex systems in which Coleopteran pollinators are trapped and released in synchrony with their circadian rhythm [46]. The floral morphology of the oldest Nymphaeales fossil, an approximately 90-million-year-old Microvictoria svitkoana Nixon, Gandolfo and Crepet fossil from the Late Cretaceous, already indicates an insect-trapping system. It is likely that its pollinators were small beetles, based on the fact that its extant relatives, the genera Victoria, Nymphaea, and Euryale Salisb., possess larger flowers and are also pollinated by larger beetles from the tribe Cyclocephalini (Scarabaeoidea, Melolonthidae) [49].

Of relict distribution, the only representative of the tribe Cyclocephalini outside America, the African species Ruteloryctes morio Fabricius, whose genus is monospecific, pollinates the hermaphroditic flowers of Nymphaea lotus L. The flowers of this species present the same specializations as those found in other cantharophilous species of the genus, namely, protogyny, nocturnal anthesis, thermogenesis, and a system of circadian trapping of floral visitors. Ervik and Knudsen (2003) [50] consider it unlikely that such a sophisticated pollination system could have evolved twice in the same genus. Taking into account the opening of the Atlantic Ocean, the authors postulate that the association between these basal aquatic angiosperms and the Cyclocephalini already existed 125-130 MYA. Specializations of Nymphaea flowers pollinated by beetles are also present in many Annonaceae species [51].

The fact that approximately $90 \%$ of Annonaceae species are pollinated by beetles and that the members of the most basal genus of this family, Anaxagorea A. St.-Hil., are also pollinated by coleopterans suggests that cantharophily is the ancestral pollination mode in the family [11]. Notwithstanding, using a phylogenetic analysis based on plastids genes, a hypothetical ancestor of the family has been reconstructed. Among other characteristics of the ancestor, the absence of floral visitor trapping and pollen dispersed as monads [13], characteristics usually observed in plants with wind pollination [52], stand out.

Knowledge obtained in recent decades about pollination modes in Annonaceae encompasses, in addition to beetles, other guilds of insects from the orders Thysanoptera [22,53,54], Diptera [55,56], Hymenoptera, represented by Euglossinae and Meliponinae bees [55,57,58], and even Blattaria [59].

In tropical forests in general and in the Cerrado in particular, apomixis-an asexual breeding system with seed set without of meiosis or fertilization-seems to be rare, and when it does occur, it is restricted to certain families (e.g., Malvaceae and Melastomataceae) $[60,61]$. Therefore, in the Cerrado, cross-pollination is dominant in forest and savanna species. The cross-reproduction rate in tropical plants normally surpasses $85 \%$. In tropical forests, such cross-pollination is facilitated, in approximately $90 \%$ of cases, by biotic vectors including beetles $[60,62,63]$. This review is the first, to the best of our knowledge, to compile data from the literature regarding beetle pollination of Annonaceae in the Cerrado.

\section{Materials and Methods}

To ensure that all relevant literature concerning beetle pollination of Annonaceae from the Cerrado were reviewed, several digital platforms were consulted (Google Scholar, 
Web of Science, ResearchGate, Academia.edu, Scielo) by applying combinations of search keywords (pollination, beetle, Coleoptera, Annonaceae, Cerrado). Since a considerable part of the studies on this topic are in Portuguese, search keywords in Portuguese were applied in separate checks. References of cited publications were also checked for related topics. The complexity and interdisciplinarity of pollination biology rendered a necessary search for studies that do not directly address cantharophily, but still contribute to its understanding such as investigations on conservation and animal behavior. A geographical overview of literature-based Cerrado study sites is shown in Figure 1.

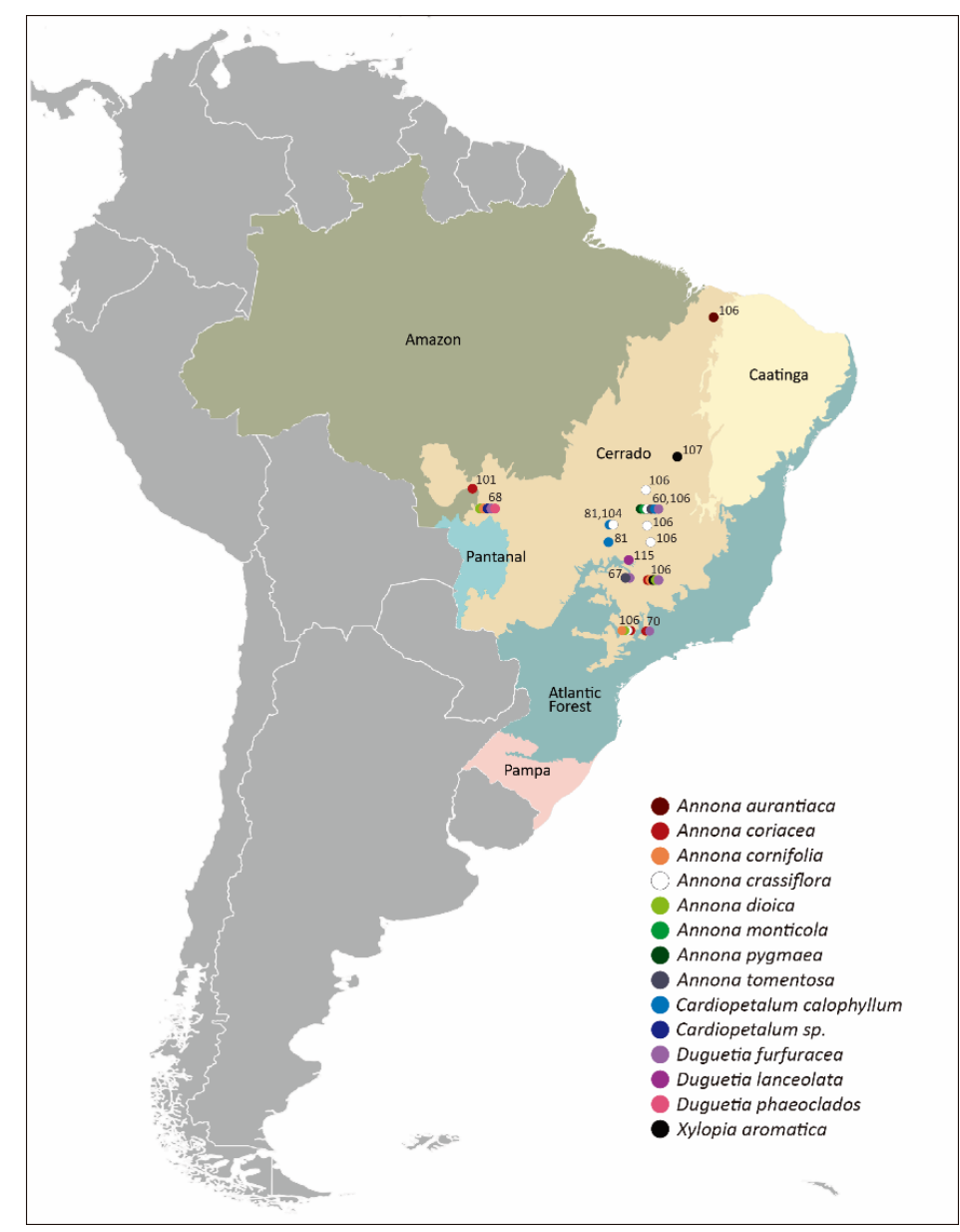

Figure 1. Brazilian biomes with Cerrado localities (circles) indicating Annonaceae study sites based on georeferenced published datasets. Circle colors refer to species, numbers to references cited. For further information, see Table 1.

\section{Shelter for the Big and for the Small: Floral Chambers in the Cerrado}

Studies on breeding systems and pollination modes in plant communities in the Cerrado have been carried out in the states of São Paulo [64-66], Minas Gerais [67], Mato Grosso [68], and in the Federal District [60]. Martins and Batalha (2006) [69] analyzed fragments of the Cerrado in the Alto Taquari region in three states: Goiás, Mato Grosso, and Mato Grosso do Sul.

Saraiva et al. (1996) [64] investigated the breeding systems of 135 trees and shrubs of anemophilous species in a Cerrado area in the municipality of Corumbatai, São Paulo.

Ishara and Maimoni-Rodella (2011) [65] worked in a Cerrado area in the municipality of Botucatu, São Paulo to study the pollination biology of 176 plant species, $92 \%$ of which were pollinated by insects. Beetles pollinated $0.5 \%$ of species, which corresponded to only one plant species: Duguetia furfuracea A. St.-Hil. of the Annonaceae. The authors point out this species as cantharophilous, referring to Gottsberger and Silberbauer-Gottsberger 
(2006) [66], following Barbosa (1997) [67], who describes the pollinator of D. furfuracea as Coleoptera sp.2. A more detailed study provided by Paulino-Neto (2009) [70], from the state of São Paulo, mentioned nitidulids of the genus Colopterus Erichson, attracted by an intense fruity odor emitted by the flowers of $D$. furfuracea, entering its floral chambers and remaining therein until the male flower phase, leaving them with a large pollen load.

In a hectare of Cerrado stricto sensu of Botucatu, Gottsberger and Silberbauer-Gottsberger (2006) [66] analyzed the pollination biology of 301 species of angiosperms, most of which (38\%) were melittophilous (i.e., pollinated by bees). Although 30 species were visited by beetles throughout the year, only eight species, or $3 \%$ of the surveyed species, were in fact pollinated by beetles. Of these eight species, five were exclusively visited by beetles. The authors found some patterns among these cantharophilous species: all of them offered pollen and tissue as resources to their pollinators. In addition, plants pollinated by small beetles such as the palms Acrocomia hassleri (Barb. Rodr.) W.J. Hahn and Syagrus loefgrenii Glassman, flowered throughout the year, whereas those pollinated by large dynastid beetles restricted their flowering period only to the rainy season, with flowering peaks in the months of November-December. Flowering during the months of the rainy season was reported for melittophilous, generalist, myophilous, and ornithophilous (bird-pollinated) species.

In this same hectare, Gottsberger and Silberbauer-Gottsberger (2006) [66] showed that $92 \%$ of plant species flowered during the day, $6 \%$ were nocturnal, and $2 \%$ apparently attracted animals on a diuturnal basis. For the six sampled Annonaceae in the area, the trend inverted: most (four species) were nocturnal, and two species had diurnal anthesis. All Annonaceae were pollinated by beetles, with the exception of Xylopia aromatica (Lam.) Mart. (Figure 2a), which was mainly pollinated by Thysanoptera and, secondarily, by beetles. The corollas of Annonaceae species, except $D$. furfuracea, whose corolla is reddish, are light in color (yellow, creamy, and white). Annonaceae specialization to cantharophily is also noteworthy when, for all plants in the area, their pollinating agents are considered functional groups (i.e., large bees, wasps, small bees, and flies). Whereas $70 \%$ of the local plant species were pollinated by more than one group of animals (generalists), only one Annonaceae species, Xylopia aromatica (Figure 2a), was pollinated by more than one functional group (small beetles and thrips).

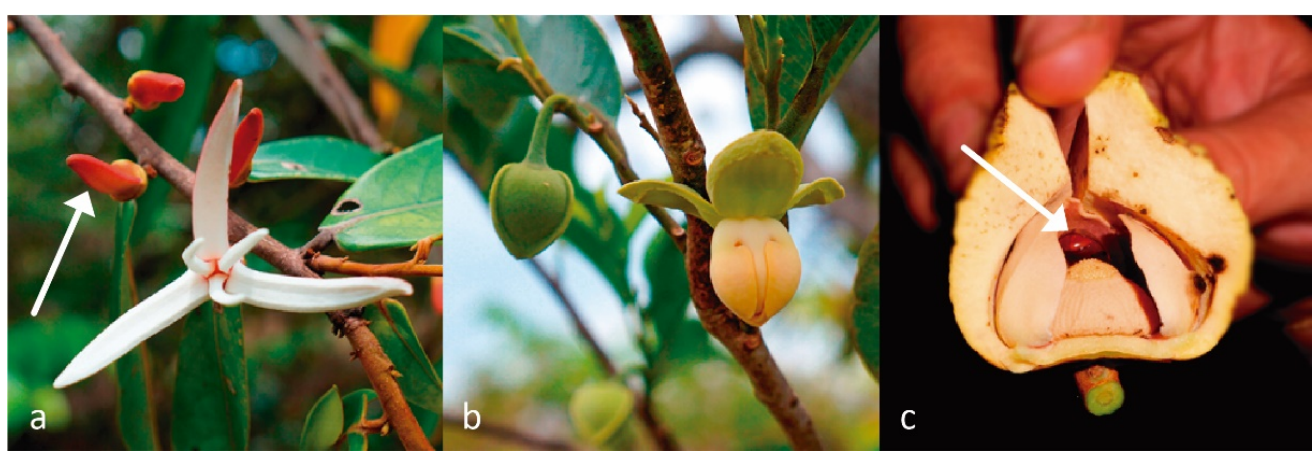

Figure 2. Flowers of three species of cantharophilous Annonaceae from our studies in the Cerrado of the Chapada dos Guimarães, MT, Brazil. Note that all three have light-colored perianths. (a) Xylopia aromatica has a mixed pollination system in which both thrips (Thysanoptera) and beetles (Coleoptera) take part. Flower visitation occurs mostly during the day, although flowers remain anthetic throughout the night. The adaxial surface of the outer petals and the linear inner petals are white. The abaxial surface of the outer petals, however, is of a vivid hue of red (arrow). (b) The calyx of Cardiopetalum calophyllum is light green, and the petals are light yellow. Flower visitation by nitidulids is diuturnal. (c) In this figure, it is possible to visualize the floral chamber of Annona crassiflora, delimited by the light yellow corolla. Pollinated by large nocturnal Cyclocephala scarabs (arrow), this species has large, thermogenic floral chambers. Note that the beetle shown inside has its head positioned toward the base of the inner petals, where the nutritious tissue patch is located. 
Floral odor in the cantharophilous species listed by Gottsberger and SilberbauerGottsberger (2006) [66] varied from fruity (D. furfuracea and Annona cornifolia A. St.-Hil.) and pungent (Annona crassiflora Mart., Annona coriacea Mart., Annona dioica A. St.-Hil.) to very sweet $(X$. aromatica).

Barbosa (1997) [67] analyzed the floral biology of 133 plant species in the herb, shrub, and canopy layers in a community of Campo Sujo in the municipality of Uberlândia, MG, Brazil, and found a high percentage of flowering species in the beginning of the rainy season, a pattern that continued until the peak in December. The blossoming of cantharophilous species intensified at the beginning of November and peaked in March. Only $1.5 \%$ of plant species were considered to be pollinated exclusively by beetles, all of which belonged to the family Annonaceae. The anthesis of two cantharophilous species included in this study, Annona tomentosa R.E. Fr., with creamy flowers, and Duguetia furfuracea, with pinkish flowers, is described as nocturnal. Floral odor was not described, and only pollen was mentioned as a resource offered by the two plant species to their coleopteran visitors. The pollinators of both species were identified taxonomically only to order. It is important to note that some other generalist species may be secondarily pollinated by beetles, but this is not explicit in taxa whose functional group of pollinators is described as several small insects, which corresponded to $5.4 \%$ of the plant species studied in the area.

Borges (2000) [68] investigated the reproductive biology of 109 woody species in a Cerrado stricto sensu area at the Federal University of Mato Grosso Experimental Farm in the municipality of Santo Antônio do Leverger, Brazil, which is located in the northern Pantanal. In this area, woody angiosperms flowered during the first three months of the rainy season (October, November, and December), after a flowering peak in September. Regarding the cantharophilous species, with the exception of D. furfuracea, which blossoms during almost all months of the year, the other Annonaceae showed a restricted flowering period starting with the onset of the rainy season. Nine (8.3\%) of the species were cantharophilous. Although the floral biology aspects of seven Annonaceae species had been observed, the pollinators of only five species were mentioned: all of these pollinators were included in the functional group beetles. The other two species were palms (Arecaceae), and likewise, their pollinators belonged to the same functional group: beetles. The resources offered by these cantharophilous species were described as pollen and tissue for Annonaceae and pollen for Arecaceae. Flower colors ranged from yellow to orange, and their anthesis was nocturnal. Only D. furfuracea had red flowers and diurnal anthesis. Floral odor was described as present for all Annonaceae species in this area.

Oliveira and Gibbs (2000) [60], in a survey encompassing 54 species of woody plants in the Brasilia Botanical Garden, found only Annona crassiflora as a cantharophilous species, and its pollinating agent was identified as Cyclocephala cf. atricapilla Mannerheim. In this study, for the sampled species, a flowering peak was detected at the end of the dry season and the beginning of the rainy season, which is the case for $A$. crassiflora. For this species, the authors referred to the resources offered to its pollinators as pollen/petals and described its flower color as reddish brown.

In the study conducted by Martins and Batalha (2006) [69], which included Cerrado fragments in three states of Central Brazil in the Alto Taquari region, trends toward diurnal anthesis (79\%) and pale-colored flowers (89\%) were detected in the 99 woody plant species whose floral biology was investigated. The three beetle-pollinated species were among the Annonaceae, namely, A. coriacea, A. crassiflora, and D. furfuracea, and corresponded to $3 \%$ of surveyed species, all of which had anthesis described as nocturnal. The two Annona L. species had yellow flowers, while the flowers of $D$. furfuracea were described as red. Only one Annonaceae sampled in the study was not classified as cantharophilous, Bocageopsis mattogrossensis R.E. Fr., whose functional group of pollinators was described as small insects.

Based on the studies reviewed, it is possible to identify some biological tendencies of the associations between beetles and cantharophilous Annonaceae species in the Cerrado. 
For a wider understanding of these associations, however, it is suitable to examine studies on the biology of certain species of beetles and Annonaceae, which will provide better comprehension of these trends.

In the Cerrado, most plant species, regardless of their pollination syndromes, normally flower in the beginning of the rainy season (generally from October through December). Batalha and Mantovani (2000) [71], without taking pollination syndromes into account, noted the same phenological pattern in the flowering of woody species in a reserve in the municipality of Santa Rita do Passa Quatro in the state of São Paulo, Brazil. Likewise, cantharophilous species generally initiate their blossoming in the beginning of the rainy season until reaching their peak from November to December [60,66-68]. However, as reported by Gottsberger and Silberbauer-Gottsberger (2006) [66], species pollinated by small beetles show a floral phenology scattered throughout the year, as is the case for D. furfuracea and certain palms.

Gottsberger (1994) [72], in a study on cantharophily in some Annonaceae species from the Cerrado, observed that flowers from this family tend to attract beetles according to their size (i.e., large flowers of the genus Annona, which flower during the initial months of the rainy season, attract large beetles of the genus Cyclocephala Dejean (Scarabaeidae, Dynastinae), while species bearing small flowers, which blossom throughout the year, attract beetles of several families, especially Nitidulidae and Staphylinidae).

Riehs (2006) [73] studied the phenology of six Cyclocephala species in the state of Paraná, Brazil. The three most abundant species were collected only in the first months of the rainy period. In another study of the Cerradão in the state of Goiás, phenological data on insects confirmed that beetles and other insects tended to be more abundant at the beginning of the rainy season, from September to November [74]. Based on this information, the woody, shrubby, and arboreal species in the Cerrado, in general, synchronize their flowering periods according to pollinator availability. The same synchronization occurs in species of the genus Annona, in accordance with the phenology of Cyclocephala beetles [66]. Data on the phenology of Staphylinidae and Nitidulidae in tropical regions, however, were not found in the reviewed literature.

There is also a gap in vision research on beetles that pollinate Annonaceae. Nonetheless, some inferences may be made based on data regarding other groups of beetles (and other insects). It has been suggested, for instance, that UV, blue, and green photoreceptors are ancestral in Insecta and that some lineages may have lost or acquired photoreceptors due to different selective pressures [75]. The pollinivorous nitidulid Melighetes aeneus Fabricius, for example, when searching for a plant on which to feed, shows a preference for yellow over green or white, although only green photoreceptors have been directly detected. Behavioral and electrophysiological tests of $M$. aeneus showed that the perception of yellow occurs via a green-versus-blue mechanism [76]. Behavioral tests of a phylogenetically distant group, Anthonomus pomorum L. (Curculionidae), supported the hypothesis that the species possesses three photoreceptors: UV, green, and blue [75]. Duplications of opsin genes have also been found in flower-visiting beetles from families Nitidulidae, Curculionidae, and Scarabaeidae, which suggests subfunctionalization of green-sensitive photopigments toward the perception of long wavelengths such as red and/or orange [77]. Intracelular measurements from the ventral portion of the eyes of the glaphyrid scarab Pygopleurus israelitus Muche, which visits certain red Mediterranean flowers, revealed the existence of UV, green, and red photoreceptors [78].

The above-mentioned examples refer to diurnal Coleoptera. However, trichromatic vision seems to be as important for nocturnal insects as it is for diurnal insects. Vision in animals with eyes adapted to nocturnal photoreception differs, basically, in the way that they capture low-intensity light [79]. The cantharophilous Annonaceae flowers with nocturnal anthesis normally bear light-colored flowers, whereas those with diuturnal and/or diurnal anthesis may also display light colors or even reddish or pinkish colors such as D. furfuracea with its red corolla (Figure 2a) [66-70]. In French Guiana, during the diuturnal anthesis of Duguetia cadaverica Huber, small mycetophagous beetles of the 
genus Pycnocnemus Sharp (Nitidulidae) are attracted, during the day, to its crimson flowers by a scent described as "reminiscent, to our noses, of very mature camembert cheese, mushrooms, and old damp socks with an additional vomit-like note" [80]. In the Central Amazon, Duguetia flagellaris Huber, pollinated by small staphylinids and nitidulids, has diurnal anthesis and wine-colored flowers, while D. ulei (Diels) R.E. Fr. and D. riparia Huber, both pollinated by Cyclocephala, possess nocturnal anthesis and creamy-yellowish flowers [22]. However, there are exceptions to such associations because Cardiopetalum calophyllum Schltdl., for instance, has diuturnal anthesis, a light green calyx, and a creamy corolla (Figure 2b). Elias et al. (2012) [81] stated that this Annonaceae is pollinated by the nitidulid Lobiopa insularis Castelnau, a species of economic relevance as a pest in fruticulture that is widely distributed in the New World [82].

The relative frequency with which many flowers show high UV reflectance must also be considered when analyzing the perception beetles have of the flowers they pollinate [76]. A greater comprehension of the interaction between beetles and Annonaceae flowers requires an experimental approach in order to test the visual perception of these pollinating beetles, especially the large nocturnal Cyclocephala and the small nitidulids and staphylinids.

The diversity within Cyclocephala, which includes c. 350 species, makes it difficult to provide generalities on the olfactive preferences in the genus. Furthermore, studies on odor emission by flowers of cantharophilous blossoms are focused on plant chemistry rather than chemoreception by floral visitors $[18,83-86]$. These studies, when analyzed either in isolation or collectively, convey remarkable convergence in phylogenetically distant plants toward the production of volatile compounds that attract beetles, especially Cyclocephala scarabs. The compound 4-methyl-5-vinylthiazole, for instance, is present in the scent of Caladium bicolor (Aiton) Vent. (Araceae) and at least four cantharophilous species of Annonaceae [18].

This guild of Annonaceae-pollinating beetles includes some species of the diverse genus Cyclocephala. Schatz (1990) [87] estimated that approximately 900 species of Neotropical angiosperms depend upon these beetles for reproduction. In the Cerrado, Annona species pollinated by nocturnal Cyclocephala have an aroma described as pungent or fruity [66]. Gottsberger (1994) [72] characterized the floral scents in this genus as aromatic, spicy, or of mature fruits. In another study, the same author described floral perfumes of cantharophilous Annonaceae as strong, fruity, spicy, or even offensive [14]. In a study comparing the floral odors of Annonaceae such as Xylopia aromatica (Figure 2a), Anaxagorea dolichocarpa Sprague \& Sandwith and Duguetia asterotricha (Diels)R.E. Fr., all of which bear small flowers with light colors and are pollinated by minute Nitidulidae, the authors discovered that, through different volatile compounds, these flowers gave off very similar fruity odors, which suggests convergent evolution to form these bouquets [83]. Flowers of $A$. dolichocarpa, present in the Cerrado, release a strong banana-like scent that attracts small beetles, mainly nitidulids that feed from their fruits. Its Amazonian relative, Anaxagorea brevipes Benth., lures beetles from the same family through a mixture of several fruit odors $[83,88]$. Nitidulids are primarily saprophagous and mycetophagous, with some genera such as Lobiopa Erichson, frequently collected on mature and/or rotting fruits $[82,89]$.

The floral cycle of Annonaceae, involving cantharophily and protogyny, causes volatile compound emissions in several taxa that are not uniform throughout anthesis but modulated according to the floral phase and/or time of day [66,72].

With the exception of Annona dioica, which is androdioecious, all Annonaceae from the Cerrado are protogynous; that is, they show temporal separation of reproductive organ functionality in which the female phase precedes the male phase $[14,66,72]$. Such a mechanism is important to avoid self-pollination in self-compatible species [90]. In $A$. crassiflora, whose flower cycle lasts one night, during the female phase hours, the odor is "fruity-nut-like with a spice note to it"; as the temperature rises, the spicy note stands out, and an unpleasant cyanide-like odor comes to dominate, remaining until the end of the male phase [66]. 
In short, beetles are attracted by the colors and odors of Annonaceae flowers and, in a symbiotic relationship, promote cross-pollination in exchange for certain resources. One of these resources is heat produced by flowers (thermogenesis). Thermogenic flowers and inflorescences are present in other botanical families such as Araceae [16-18,20,84,91], Arecaceae [21,22], Cyclanthaceae [16,25,92], Magnoliaceae [31,32], and Nymphaeaceae [50], and even in cantharophilous gymnosperms [37]. According to these references, thermogenesis events, in the majority of species from these families, are mostly linked to the period of nocturnal anthesis and the attraction of nocturnal Cyclocephala.

For some years, there has been a debate on the validity of considering the heat emitted by these flowers as, in addition to being an attractant, a resource energetically usable by flower visitors [93-99]. Meeuse and Raskin (1988) [93], in a bibliographic review regarding thermogenesis in Araceae, mention only the function of endogenous production of heat as an odor intensifier, that is, as an attractant for pollinators. Dieringer et al. (1998) [95], measuring thoracic temperatures of Cyclocephala caelestis Delgado \& Ratcliffe, concluded that they were independent of ambient and floral temperatures of Magnolia tamaulipana A. Vázquez, ruling out the possibility that these flowers acted as a resource for these beetles. However, Seymour et al. (2009) [99], with an experimental approach, found that within the thermogenic inflorescences of the aroid Philodendron solimoesense A.C. Sm., beetles of the species Cyclocephala colasi Endrödi did not thermoregulate, as opposed to when they were outside the inflorescences. The authors concluded that inside the inflorescences, beetles could feed and breed throughout the night, avoiding the costs of endothermy.

Floral thermogenesis has been widely reported in cantharophilous Annonaceae species from the Cerrado $[14-16,66,70,72,100,101]$ (see summary Table 1 for details). The protogynous flowers of $A$. coriacea exhibit a flowering cycle that lasts two days. During the first night hours, the female phase initiates: flowers heat up and give off an intense sweet odor, attracting dynastid beetles. Only during the following nightfall do flowers enter the male phase, again producing heat emitting odor and attracting pollinators. Thermogenesis during the female phase may lead to temperatures as much as $15^{\circ} \mathrm{C}$ above the ambient temperature. In the states of São Paulo and Minas Gerais, Brazil, the principal pollinator of A. coriacea is Cyclocephala atricapilla, with Cyclocephala quatuordecimpunctata Mannerheim occasionally serving as a pollinator (Figure 3c) [72]. In the Cerrado of the municipality of Nova Marilândia, in the state of Mato Grosso, Brazil, in addition to C. atricapilla, four other species of the tribe Cyclocephalini have also been observed visiting flowers and departing from them with their bodies covered in pollen: Cyclocephala undata Olivier, C. octopuntata Burmeister, Cyclocephala ohausiana Höhne, and even Arrigutia brevissima Arrow [66,101].

The smaller A. cornifolia flowers also show nocturnal anthesis that lasts two days, with a female phase on the first night and a male phase on the second night, but thermogenesis is more moderate (yielding temperatures up to $8.5^{\circ} \mathrm{C}$ above the ambient temperature). In the Cerrados of the Brazilian states of Minas Gerais and São Paulo, the fruity smell of A. cornifolia attracts primarily C. quatuordecimpunctata and, secondarily, C. atricapilla. The species C. atricapilla is the main pollinator of five additional Annona species present in the Cerrado, namely, Annona aurantiaca Barb. Rodr., A. dioica, Annona monticola Mart., Annona warmingiana Mello-Silva \& Pirani, and A. crassiflora [14,66,72], whose anthesis is detailed below.

The beginning of the rainy season coincides with leaf sprouting in A. crassiflora (Figure 3), locally known as araticum. The nearly solitary floral buds, which take months to develop, acquire a ferruginous-yellow coloration, and the flowering period commences, with a few flowers opening up each night at the beginning of the rainy season and commencement of an intense blossoming phase between November and December. The corolla has two whorls: the most basal one is composed of three external fleshy and thick petals, whose abaxial face is ferruginous-tomentose and at times greenish and lighter (Figure 3a); the abaxial face is somewhat concave, cream-colored on the edges, and characterized by a distinct crimson patch on its basal third. The external petals thicken from base to apex, showing a retuse to acute shape (Figures $2 c$ and $3 b-f$ ). The most apical whorl of the 
perianth is formed by alternating outer petals and inner light-yellow petals, the latter of which are much smaller and thinner but rigid and with a shape similar to that of the outer petals (Figure 3b-f). At the base of the inner petals, on the adaxial surface, there are two distinct basal lobes that are small and laterally positioned (Figure 3f). The mature flower is pendant and shows a fruit-like aspect, with external petals lightly parted just enough for Cyclocephala to pass through (Figure 3a) [14,66,72,102,103].

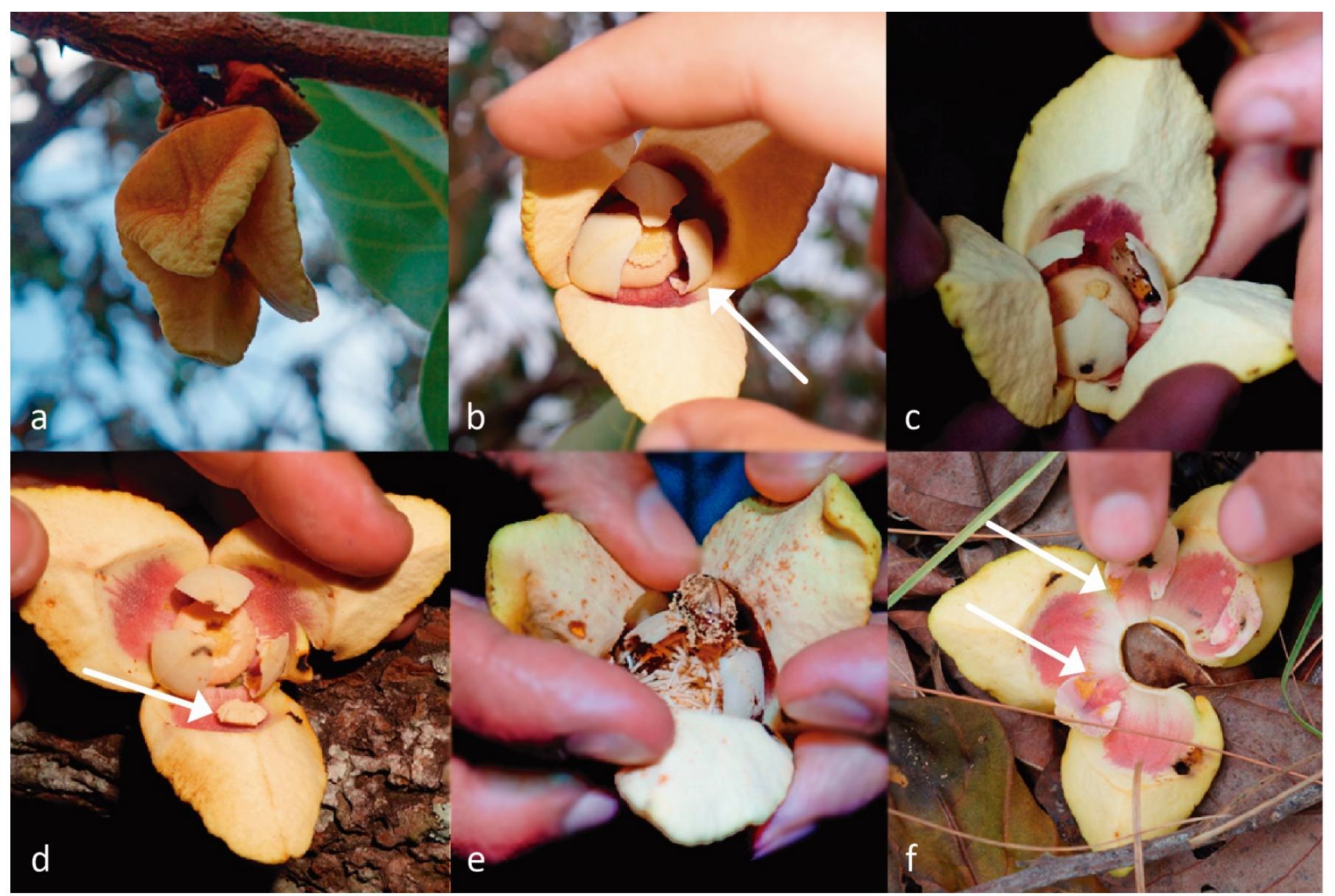

Figure 3. Stages of anthesis of Annona crassiflora. (a) The fruit-like flower has outer petals with a yellow and ferruginoustomentose abaxial surface. Anthesis begins during the early evening hours. (b) The female phase is marked by the production of stigmatic exudate by the gynoecium (arrow). Here, the thicker outer petals and the smaller and thinner inner petals are shown. (c) A Cyclocephala quatuordecimpunctata individual feeding on the basal lobe of an inner petal during the female phase. (d) Before entering the male phase, the gynoecium detaches from the receptacle (arrow). Note the purple to reddish basal patch on the inner petals. (e) Cyclocephala celata visiting a male-phase flower, with its anthers detached and dehisced. (f) The shed corolla from a flower on the day after anthesis showing herbivory marks (arrows) of Cyclocephala spp. At the spot where the basal lobes are located (data from authors own studies).

The flowers open up during the day, but anthesis, defined as the period in which the flowers are active, occurs for only one night. During crepuscular hours, the flowers heat up and give off a fruity smell that attracts Cyclocephala, and the gynoecium becomes covered with a transparent and viscous substance, which marks the onset of the female phase (Figure 3b). Between $22 \mathrm{~h}$ and midnight, the flowers enter the male phase: the stigmatic head detaches from the receptacle, and the anthers dehisce, releasing pollen on the inside of the floral chamber (Figure $3 \mathrm{~d}, \mathrm{e}$ ). Still during the late night, the gamopetalous corolla detaches from the receptacle and drops, marking the end of anthesis (Figure 3f) $[14,66,72,104]$.

In addition to providing protection against desiccation and predators, a mating site, and heat, A. crassiflora flowers, like those of other species of the genus, also offer alimentary 
resources to their visitors. During the female phase of the flowers, beetles may feed on the basal lobes of the inner petals (Figure 3c,f), while pollen is offered as an alimentary resource during the male phase $[14,66,72]$. Histochemical analyses of $A$. crassiflora inner petals revealed that their basal lobes are nutritious tissues rich in lipids and starch that, in addition to providing food to their pollinators, may also serve as fuel for the metabolism of floral thermogenesis [105]. Even after the end of the floral cycle, the fallen corolla of $A$. crassiflora persists as a unit (Figure $3 \mathrm{f}$ ) that protects beetles from desiccation and predators, where the beetles often remain until the upcoming night, when they head to other anthetic flowers [14,66,72].

Although Gerhard Gottsberger has studied pollination in A. crassiflora individuals located over $1000 \mathrm{~km}$ away, C. atricapilla has been shown to be its principal pollinator in the Cerrados of almost all sampled Brazilian states such as Goiás, São Paulo, and Minas Gerais, and the Federal District [66]. Nevertheless, there were rare observations of C. quatuordecimpunctata (Figure 3c) and Cyclocephala literata Burmeister, a species that was found by the same author and collaborators in another study, pollinating Magnolia ovata (A. St.-Hil.) Spreng. (Magnoliaceae) in the Atlantic Forest [32,66].

Gottsberger (1989) [106] also noted that although there is a certain degree of temporal overlap among the sympatric flowering species of Annona from the Cerrado, their flowering peaks are arranged sequentially, which, in addition to constituting a genetic barrier against hybridization between these related plants, also hinders competition for pollinators among them and provides Cyclocephala spp. with protection and breeding and feeding sites during four months of the year. In the same study, the author posed the hypothesis, yet to be tested, that a larger number of Cyclocephala species pollinates the forest species of Annona [106].

Based on the reviewed examples, especially those of $A$. coriacea, there do not seem to be species-specific relationships between species of Annonaceae and species of pollinating beetles. In this case, geographic variables appear to influence the taxonomic composition of Cyclocephala that pollinate Annona species, with regional differences. Even so, when the Cyclocephalini are considered only one functional group, it is apparent that this is a specialized pollination relationship [66]. As previously shown, the other functional group associated with cantharophilous Annonaceae from the Cerrado comprises small beetles from the families Nitidulidae and Staphylinidae, which pollinate species with small flowers and diurnal or diuturnal anthesis.

Regardless, in both pollination modes, both large and small nectarless flowers of the Annonaceae offer a relatively isolated place where pollinators may find shelter against desiccation and predators and a place to mate with conspecifics and to find food. This place is called, almost invariably, a floral chamber [14-16,66,70,72,100,101,107]. 
Table 1. Summary of reviewed literature with records of cantharophily in Cerrado Annonaceae.

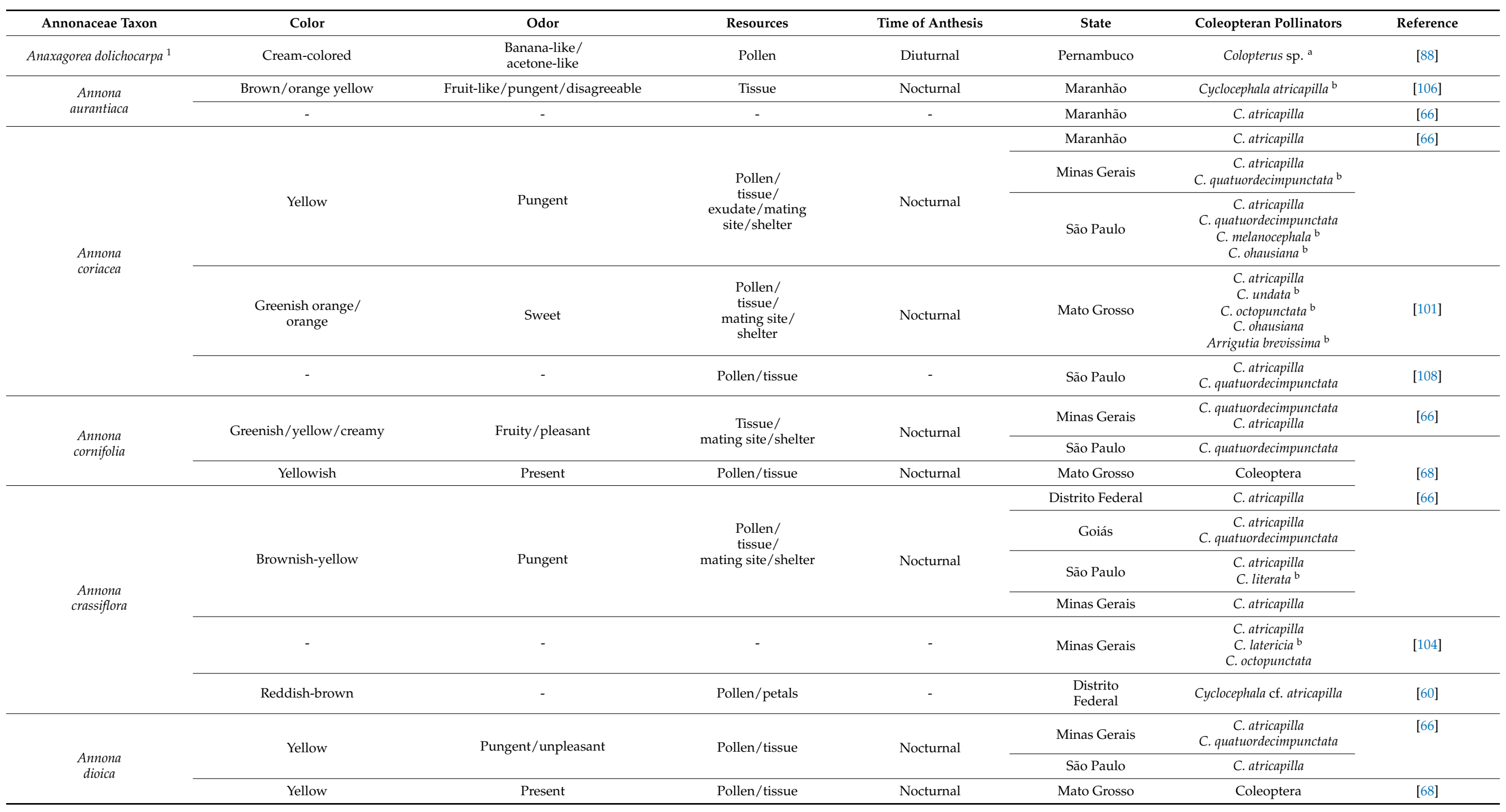


Table 1. Cont.

\begin{tabular}{|c|c|c|c|c|c|c|c|}
\hline Annonaceae Taxon & Color & Odor & Resources & Time of Anthesis & State & Coleopteran Pollinators & Reference \\
\hline $\begin{array}{c}\text { Annona } \\
\text { monticola }\end{array}$ & - & Unpleasant & - & - & Distrito Federal & C. atricapilla & {$[66]$} \\
\hline \multirow{5}{*}{$\begin{array}{c}\text { Annona } \\
\text { tomentosa }\end{array}$} & \multirow{4}{*}{ Yellowish } & \multirow{4}{*}{$\begin{array}{l}\text { Fruit-like/ } \\
\text { agreeable }\end{array}$} & \multirow{4}{*}{ - } & & \multirow{2}{*}{ Distrito Federal } & C. atricapilla & {$[106]$} \\
\hline & & & & - & & C. quatuordecimpunctata & \\
\hline & & & & & \multirow{2}{*}{ Minas Gerais } & C. quatuordecimpunctata & \\
\hline & & & & & & C. atricapilla & \\
\hline & Creamy & Present & Pollen & Nocturnal & Minas Gerais & Coleoptera & [67] \\
\hline $\begin{array}{c}\text { Annona } \\
\text { pygmaea } \\
\text { [syn. A. warmingiana] }\end{array}$ & - & $\begin{array}{l}\text { Fruit-like/ } \\
\text { unpleasant }\end{array}$ & - & - & Distrito Federal & C. atricapilla & {$[106]$} \\
\hline Cardiopetalum sp. & Yellow & Present & Pollen/tissue & Nocturnal & Mato Grosso & Coleoptera & [68] \\
\hline \multirow{4}{*}{$\begin{array}{l}\text { Cardiopetalum } \\
\text { calophyllum }\end{array}$} & - & Decaying fruit & - & Diurnal & Distrito Federal & Lobiopa spp. ${ }^{a}$ & [66] \\
\hline & - & - & - & - & Goiás & Lobiopa insularis a & [81] \\
\hline & \multirow{2}{*}{ Greenish/white } & \multirow{2}{*}{ Present } & \multirow{2}{*}{-} & \multirow{2}{*}{ Nocturnal } & \multirow{2}{*}{ Minas Gerais } & Chrysomelidae & [109] \\
\hline & & & & & & Coccinelidae & \\
\hline \multirow{7}{*}{$\begin{array}{l}\text { Duguetia } \\
\text { furfuracea }\end{array}$} & \multirow{4}{*}{ Red } & \multirow{4}{*}{$\begin{array}{c}\text { Fruity/ } \\
\text { decaying fruit }\end{array}$} & \multirow{4}{*}{-} & \multirow{4}{*}{ Diurnal } & \multirow{2}{*}{$\begin{array}{l}\text { Distrito } \\
\text { Federal }\end{array}$} & Nitidulidae spp. & {$[66]$} \\
\hline & & & & & & $\begin{array}{l}\text { Curculionidae aff. } \\
\text { Prantisus sp. }\end{array}$ & \\
\hline & & & & & \multirow[b]{2}{*}{ Minas Gerais } & Lobiopa sp. & \\
\hline & & & & & & $\begin{array}{l}\text { Curculionidae aff. } \\
\text { Prantisus sp. }\end{array}$ & \\
\hline & Dark red/purple & Mature fruit & - & Diuturnal & São Paulo & Colopterus sp. & [70] \\
\hline & Red & Present & Pollen/tissue & Diuturnal & Mato Grosso & Coleoptera & [68] \\
\hline & Rosy & Undetected & Pollen & Nocturnal & Minas Gerais & Coleoptera & [67] \\
\hline \multirow{2}{*}{$\begin{array}{l}\text { Duguetia } \\
\text { lanceolata }\end{array}$} & \multirow{2}{*}{ Purple/reddish-orange } & \multirow{2}{*}{ Characteristic } & \multirow{2}{*}{-} & \multirow{2}{*}{ Diuturnal } & \multirow{2}{*}{ Minas Gerais } & Chrysomelidae & [109] \\
\hline & & & & & & Coccinelidae & \\
\hline $\begin{array}{c}\text { Duguetia } \\
\text { phaeoclados } \\
\text { [syn. Annona phaeoclados] }\end{array}$ & Yellow & Present & $\begin{array}{l}\text { Pollen/ } \\
\text { tissue }\end{array}$ & Nocturnal & Mato Grosso & Coleoptera & [68] \\
\hline
\end{tabular}


Table 1. Cont.

\begin{tabular}{|c|c|c|c|c|c|c|c|}
\hline Annonaceae Taxon & Color & Odor & Resources & Time of Anthesis & State & Coleopteran Pollinators & Reference \\
\hline \multirow{6}{*}{$\begin{array}{c}\text { Xylopia } \\
\text { aromatica }\end{array}$} & \multirow{5}{*}{ White } & \multirow{5}{*}{ Very sweet } & \multirow{5}{*}{ Pollen/tissue } & \multirow{5}{*}{ Diurnal } & \multirow{2}{*}{ Amazonas } & Chrysomelidae sp. & [66] \\
\hline & & & & & & Nitidulidae spp. & \\
\hline & & & & & Minas Gerais & $\begin{array}{l}\text { Thysanoptera spp. } \\
\text { Chrysomelidae sp. } \\
\text { Cillaeus sp. }{ }^{\mathrm{a}} \\
\text { Carpophilinae sp. }{ }^{\text {a }}\end{array}$ & \\
\hline & & & & & Mato Grosso & Cillaeus sp. & \\
\hline & & & & & São Paulo & $\begin{array}{l}\text { Halticinae sp. }{ }^{c} \\
\text { Cillaeus sp. }\end{array}$ & \\
\hline & - & Undetected & - & Diuturnal & Bahia & Curculionidae sp. & [107] \\
\hline
\end{tabular}

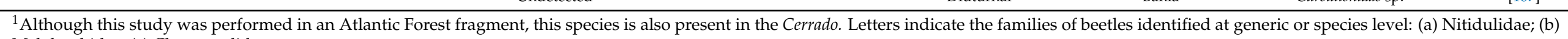
Melolonthidae; (c) Chrysomelidae. 


\section{Beetle Marks and Other Mysteries}

With regard to cantharophily, Bernhardt (2000) [51], analyzing the noteworthy evolutionary convergence among phylogenetically distant angiosperm groups, defined four modes of floral presentation, which he termed bilabiate, brush, chamber blossom, and painted bowl, whose traits may overlap. The bilabiate floral presentation occurs, for instance, in some Lowiaceae and Orchidaceae pollinated by Cantharidae and Coccinelidae, while the brush mode is present, for example, in palms pollinated by Curculionidae. The painted bowl mode occurs in certain tulips and Iridaceae from Mediterranean regions and Africa $[51,110]$. The petals of this type possess beetle marks, which consist of symmetrically oriented spots restricted to the perianth base, normally of vivid colors contrasting against a light background. The colors of beetle marks range from orange-yellowish, pink, red, and dark-brown to dark iridescent. Bernhardt (2000) [51] remarked that tests with UV light have not been performed and that thermogenesis has not been investigated in the painted bowl form. Although there is some evidence of their role as visual signals, the function of beetle marks as attractants to coleopteran pollinators remains poorly understood $[51,110]$. It is clear that, in general, Annonaceae from the Cerrado mostly show the chamber blossom mode, but it is tempting to hypothesize some overlap with the painted bowl mode in cases of the symmetrically oriented and crimson patches on the external petals of $A$. crassiflora (Figure 3) and A. cornifolia.

From the viewpoint of the beetles' natural history, gaps in pollination studies focusing on the sensorial perception of the Coleoptera are evident. Furthermore, behavioral observation of the nocturnal Cyclocephala is hindered by these animals' negative phototaxis and by the nature of the floral chamber, which must be obliterated so that its interior can be observed, interrupting the activities of the beetles and influencing their behavior (authors observations) [66]. Additionally, regarding Annonaceae pollinated by small beetles, taxonomic identification of floral visitors to the species level, and at times even the genus level, is rare. Due to a lack of specialists, overcoming such obstacles is difficult.

\section{Outlook}

Access to Brazilian Cerrado areas with a good number of Annonaceae species to be studied is becoming increasingly difficult, as the dramatic alteration in land use in this phytogeographical domain is swiftly shrinking the continuous areas of the biome. In four decades, half of the natural landscape has been modified, and only $2.5 \%$ of the total Cerrado area is in conservation units [111].

Although Annonaceae pollinators such as Cyclocephala spp. cause economic damage to some cultivars, there are few well-documented records on the conditions in which the adults become pests [112]. In Brazil, exotic species of Annona such as Annona squamosa L. (sugar apple) and Annona muricata L. (soursop) $[108,113,114]$ are grown at a large scale. There is a record of six Cyclocephala species visiting A. muricata in Brazil, among which is Cyclocephala celata Dechambre (Figure 3e), which stands out as a potential pollinator because it is the most abundant species in the flowers of these species [115]. Annona crassiflora fruits, whose commercial potential is yet underexplored, are greatly appreciated by the rural populations in Central Brazil and are sold at fairs [103]. Research is urgently needed to illuminate the functional traits and ecosystem services of these symbiotic relationships between beetles and Cerrado angiosperms.

Author Contributions: Conceptualization, F.P.S., K.-L.S. and M.I.M.; Methodolgy, F.P.S., K.-L.S. and M.I.M.; Software, F.P.S.; Validation: F.P.S., K.-L.S. and M.I.M.; Formal analysis, F.P.S., K.-L.S. and M.I.M.; Investigation, F.P.S.; Resources, M.I.M. and K.-L.S.; Data curation, F.P.S. and M.I.M.; Writingoriginal draft preparation, F.P.S.; Writing—review and editing, K.-L.S. and M.I.M.; Visualization, M.I.M., F.P.S. and K.-L.S.; Supervision, K.-L.S. and M.I.M.; Project administration, M.I.M. and K.-L.S. All authors have read and agreed to the published version of the manuscript. 
Funding: F.P.S. was supported by a grant from the Coordenação de Aperfeiçoamento de Pessoal de Nivel Superior, Brazil (CAPES), Finance Code 001. K.-L.S. was supported by the Brehm Funds for International Bird Conservation, Bonn, Germany.

Institutional Review Board Statement: Not applicable.

Informed Consent Statement: Not applicable.

Data Availability Statement: Not applicable.

Acknowledgments: We thank Ana Silvia Tissiani (INAU/UFMT) for the technical support.

Conflicts of Interest: The authors declare no conflict of interest.

\section{References}

1. Labandeira, C.C. Insect mouthparts: Ascertaining the paleobiology of insect feeding strategies. Annu. Rev. Ecol. Syst. 1997, 28, 153-193. [CrossRef]

2. Hunt, T.; Bergsten, J.; Levkanicova, Z.; Papadopoulou, A.; St. John, O.; Wild, R.; Hammond, P.M.; Ahrens, D.; Balke, M.; Caterino, M.S.; et al. A comprehensive phylogeny of beetles reveals the evolutionary origins of a superradiation. Science 2007, 318, 1913-1916. [CrossRef] [PubMed]

3. Ikeda, H.; Nishikawa, M.; Sota, T. Loss of flight promotes beetle diversification. Nat. Commun. 2012, 3, 648. [CrossRef] [PubMed]

4. McKenna, D.D.; Wild, A.L.; Kanda, K.; Bellamy, C.L.; Beutel, R.G.; Caterino, M.S.; Farnum, C.W.; Hawks, D.C.; Ivie, M.A.; Jameson, M.L.; et al. The beetle tree of life reveals that Coleoptera survived end-Permian mass extinction to diversify during the Cretaceous terrestrial revolution. Syst. Entomol. 2015, 40, 835-880. [CrossRef]

5. Labandeira, C.C. The role of insects in Late Jurassic to Middle Cretaceous Ecosystems. In Lower and Middle Cretaceous Terrestrial Ecosystems; Lucas, S.G., Kirkland, J.I., Estep, J.W., Eds.; New Mexico Museum of Natural History and Science: Albuquerque, NM, USA, 1998; pp. 105-124.

6. Wang, B.; Zhang, H.; Jarzembowski, E.A. Early Cretaceous angiosperms and beetle evolution. Front. Plant Sci. 2013, 4, 360. [CrossRef]

7. Saunders, R.M.K. The evolution of key functional floral traits in the early divergent angiosperm family Annonaceae. J. Syst. Evol. 2020, 58, 369-392. [CrossRef]

8. Gottsberger, G. Comments on flower evolution and beetle pollination in the genera Annona and Rollinia. Plant Syst. Evol. 1989, 167, 189-194. [CrossRef]

9. Souza, V.C.; Lorenzi, H. Botânica Sistemática: Guia Ilustrada para Identificação das Famílias Nativas e Exóticas no Brasil, Baseado em APG III; Instituto Plantarum: Nova Odessa, Brazil, 2012.

10. Teixeira, S.P.; Marinho, C.R.; Paulino, J.V. A flor: Aspectos morfofuncionais e evolutivos. In Biologia da Polinização; Rech, A.R., Agostini, K., Oliveira, P.E., Machado, I.C., Eds.; Projeto Cultural: Rio de Janeiro, Brazil, 2014; pp. 45-69.

11. Gottsberger, G. The reproductive biology of the early-divergent genus Anaxagorea (Annonaceae), and its significance for the evolutionary development of the family. Acta Bot. Bras. 2016, 30, 313-325. [CrossRef]

12. Couvreur, T.L.P.; Helmstetter, A.J.; Koenen, E.J.M.; Bethune, K.; Brandão, R.D.; Little, S.A.; Sauquet, H.; Erkens, R.H.J. Phylogenomics of the major tropical plant family Annonaceae using targeted enrichment of nuclear genes. Front. Plant Sci. $2019,9,1491$. [CrossRef]

13. Xue, B.; Guo, X.; Landis, J.B.; Sun, M.; Tang, C.C.; Soltis, P.S.; Soltis, D.E.; Saunders, R.M.K. Accelerated diversification correlated with functional traits shapes extant diversity of the early-divergent angiosperm family Annonaceae. Mol. Phylogenet. Evol. 2020, 142, 106659. [CrossRef]

14. Gottsberger, G. Pollination and evolution in Neotropical Annonaceae. Plant Species Biol. 1999, 14, 143-152. [CrossRef]

15. Paulino-Neto, H.F. Polinização por besouros. In Biologia da Polinização; Rech, A.R., Agostini, K., Oliveira, P.E., Machado, I.C., Eds.; Projeto Cultural: Rio de Janeiro, Brazil, 2014; pp. 259-276.

16. Gottsberger, G. Flowers and beetles in the South American Tropics. Bot. Acta 1990, 103, 360-365. [CrossRef]

17. Gibernau, M.; Barabé, D.; Cerdan, P.; Dejean, A. Beetle pollination of Philodendron solimoesense (Araceae) in French Guiana. Int. J. Plant Sci. 1999, 160, 1135-1143. [CrossRef] [PubMed]

18. Maia, A.C.D.; Gibernau, M.; Dötterl, S.; Navarro, D.M.A.F.; Seifert, K.; Müller, T.; Schlindwein, C. The floral scent of Taccarum ulei (Araceae): Attraction of scarab beetle pollinators to an unusual aliphatic acyloin. Phytochemistry 2013, 93, 71-78. [CrossRef]

19. Pereira, J.; Schlindwein, C.; Antonini, Y.; Maia, A.C.D.; Dötterl, S.; Martins, C.; Navarro, D.M.A.F.; Oliveira, R. Philodendron adamantinum (Araceae) lures its single cyclocephaline scarab pollinator with specific dominant floral scent volatiles. Biol. J. Linn. Soc. Lond. 2014, 111, 679-691. [CrossRef]

20. Milet-Pinheiro, P.; Gonçalves, E.G.; Navarro, D.M.A.F.; Nuñez-Avellaneda, L.A.; Maia, A.C.D. Floral scent chemistry and pollination in the Neotropical aroid genus Xanthosoma (Araceae). Flora 2017, 231, 1-10. [CrossRef]

21. Silberbauer-Gottsberger, I. Pollination and evolution in palms. Phyton 1990, 30, 213-233.

22. Küchmeister, H.; Webber, A.C.; Silberbauer-Gottsberger, I.; Gottsberger, G. A polinização e sua relação com a termogênese em espécies de Arecaceae e Annonaceae da Amazônia Central. Acta Amazon. 1998, 28, 217-245. [CrossRef] 
23. Oliveira, M.S.P.; Couturier, G.; Beserra, P. Biologia da polinização da palmeira tucumã (Astrocaryum vulgare Mart.) em Belém, Pará, Brasil. Acta Bot. Bras. 2003, 17, 343-353. [CrossRef]

24. De Medeiros, B.A.S.; Núñez-Avellaneda, L.A.; Hernandez, A.M.; Farrell, B.D. Flower visitors of the licuri palm (Syagrus coronata): Brood pollinators coexist with a diverse community of antagonists and mutualists. Biol. J. Linn. Soc. Lond. 2019, 126, 666-687. [CrossRef]

25. Eriksson, R. The remarkable weevil pollination of the Neotropical Carludovicoideae (Cyclanthaceae). Plant Syst. Evol. 1994, 189, 75-81. [CrossRef]

26. Franz, N.M.; Valente, R.M. Evolutionary trends in derelomine flower weevils (Coleoptera: Curculionidae): From associations to homology. Invertebr. Syst. 2005, 19, 499-530. [CrossRef]

27. Moore, M.R.; Jameson, M.L. Floral associations of Cyclocephaline scarab beetles. J. Insect Sci. 2013, 13, 100. [CrossRef] [PubMed]

28. Valente, R.M.; Da Silva, P.A.L.; De Medeiros, B.A.S. The first species of Cotithene Voss (Coleoptera: Curculionidae: Curculioninae) from Amazonian Brazil, with notes on its role as a pollinator of Evodianthus funifer (Poit.) Lindm. (Cyclanthaceae). Zootaxa 2019, 4576, 461-482. [CrossRef] [PubMed]

29. Dieringer, G.; Espinosa, J.E. Reproductive ecology of Magnolia schiedeana (Magnoliaceae), a threatened cloud forest tree species in Veracruz, Mexico. Bull. Torrey Bot. Club. 1994, 121, 154-159. [CrossRef]

30. Thien, L.B.; Kawano, S.; Devall, M.; Latimer, S.; Rosso, S.; Azuma, H.; Jobes, D.V. Fluorescent Magnolia flowers. Plant Species Biol. 1995, 10, 61-64. [CrossRef]

31. Dieringer, G.; Cabrera, R.L.; Lara, M.; Loya, L.; Reyes-Castillo, P. Beetle pollination and floral thermogenicity in Magnolia tamaulipana (Magnoliaceae). Int. J. Plant Sci. 1999, 160, 64-71.

32. Gottsberger, G.; Silberbauer-Gottsberger, I.; Dötterl, S. Pollination ecology of Magnolia ovata may explain the overall large flower size of the genus. Flora 2012, 207, 107-118. [CrossRef]

33. Singer, R.B.; Cocucci, A.A. Pollination of Pteroglossaspis ruwenzoriensis (Rendle) Rolfe (Orchidaceae) by beetles in Argentina. Bot. Acta 1997, 110, 338-342. [CrossRef]

34. Steiner, K.E. The evolution of beetle pollination in a South African Orchid. Am. J. Bot. 1998, 85, 1180-1193.

35. Peter, C.I.; Johnson, S.D. Pollination by flower chafer beetles in Eulophia ensata and Eulophia welwitschii (Orchidaceae). S. Afr. J. Bot. 2009, 75, 762-770. [CrossRef]

36. Tang, W. Insect pollination in the cycad Zamia pumila (Zamiaceae). Am. J. Bot. 1987, 74, 90-99. [CrossRef]

37. Norstog, K.J.; Fawcett, P.K.S.; Vovides, A.P. Beetle pollination of two species of Zamia: Evolutionary and ecological considerations. Palaeobotanist 1992, 41, 149-158.

38. Sakai, S. A review of brood-site pollination mutualism: Plants providing breeding sites for their pollinators. J. Plant Res. 2002, 115, 161-168. [CrossRef] [PubMed]

39. Kono, M.; Tobe, H. Is Cycas revoluta (Cycadaceae) wind- or insect-pollinated? Am. J. Bot. 2007, 94, 847-855. [CrossRef] [PubMed]

40. Cousins, S.R.; Witkowski, E.T.F. African cycad ecology, ethnobotany and conservation: A synthesis. Bot. Rev. 2017, 83, 152-194. [CrossRef]

41. Rech, A.R.; Bergamo, P.J.; Figueiredo, R.A. Polinização abiótica. In Biologia da Polinização; Rech, A.R., Agostini, K., Oliveira, P.E., Machado, I.C., Eds.; Projeto Cultural: Rio de Janeiro, Brazil, 2014; pp. 183-204.

42. Henderson, A. A review of pollination studies in the Palmae. Bot. Rev. 1986, 52, 221-259. [CrossRef]

43. Hu, S.; Dilcher, D.L.; Taylor, D.W. Pollen evidence for the pollination biology of early flowering plants. In Evolution of PlantPollinator Relationships; Patiny, S., Ed.; Cambridge University Press: Cambridge, UK, 2012; pp. 165-236.

44. Li, H.T.; Yi, T.S.; Gao, L.M.; Ma, P.F.; Zhang, T.; Yang, J.B.; Gitzendanner, M.A.; Fritsch, P.W.; Cai, J.; Luo, Y.; et al. Origin of angiosperms and the puzzle of the Jurassic gap. Nat. Plants 2019, 5, 461-470. [CrossRef] [PubMed]

45. Van der Kooi, C.J.; Ollerton, J. The origins of flowering plants and pollinators. Science 2020, 368, $1306-1308$.

46. Thien, L.B.; Bernhardt, P.; Devall, M.S.; Chen, Z.D.; Luo, Y.B.; Fan, J.H.; Yuan, L.C.; Williams, J.H. Pollination biology of basal angiosperms (ANITA Grade). Am. J. Bot. 2009, 96, 166-182. [CrossRef]

47. Labandeira, C.C. Fossil history and evolutionary ecology of Diptera and their associations with plants. In The Evolutionary Biology of Flies; Yeats, D.K., Wiegmann, D.M., Eds.; Columbia University Press: New York, NY, USA, 2005; pp. 217-273.

48. Paccini, E.; Hesse, M. Pollenkitt-its composition, forms and functions. Flora 2005, 200, 399-415. [CrossRef]

49. Gandolfo, M.A.; Nixon, K.C.; Crepet, W.L. Cretaceous flowers of Nymphaeaceae and implications for complex insect entrapment pollination mechanisms in early angiosperms. Proc. Natl. Acad. Sci. USA 2004, 101, 8056-8060. [CrossRef]

50. Ervik, F.; Knudsen, J.T. Water lilies and scarabs: Faithful partners for 100 million years? Biol. J. Linn. Soc. Lond. 2003, 80, 539-543. [CrossRef]

51. Bernhardt, P. Convergent evolution and adaptive radiation of beetle-pollinated angiosperms. Plant Syst. Evol. 2000, 222, 293-320. [CrossRef]

52. Friedman, J.; Barrett, S.P.C. A phylogenetic analyses of the evolution of wind pollination in the angiosperms. Int. J. Plant Sci. 2008, 169, 49-58. [CrossRef]

53. Webber, A.C.; Gottsberger, G. Floral biology and pollination of Bocageopsis multiflora and Oxandra euneura in Central Amazonia, with remarks on the evolution of stamens in Annonaceae. Feddes Repert. 1995, 106, 515-524. [CrossRef] 
54. Momose, K.; Nagamitsu, T.; Inoue, T. Thrips cross-pollination of Popowia pisocarpa (Annonaceae) in a lowland dipterocarp forest in Sarawak. Biotropica 1998, 30, 444-448. [CrossRef]

55. Silberbauer-Gottsberger, I.; Gottsberger, G.; Webber, A.C. Morphological and functional flower characteristics of New and Old World Annonaceae with respect to their mode of pollination. Taxon 2003, 52, 701-718. [CrossRef]

56. Gottsberger, G.; Meinke, S.; Porembski, S. First records of flower biology and pollination in African Annonaceae: Isolona, Piptostigma, Uvariodendron, Monodora and Uvariopsis. Flora 2011, 206, 498-510. [CrossRef]

57. Carvalho, R.; Webber, A.C. Biologia floral de Unonopsis guatterioides (A.D.C.) R.E. Fr., uma Annonaceae polinizada por Euglossini. Rev. Bras. Bot. 2000, 23, 421-425. [CrossRef]

58. Teichert, H.; Dötterl, S.; Zimma, B.; Ayasse, M.; Gottsberger, G. Perfume-collecting male euglossine bees as pollinators of a basal angiosperm-the case of Unonopsis stipitata. Plant Biol. 2008, 11, 29-37. [CrossRef]

59. Nagamitsu, T.; Inoue, T. Cockroach pollination and breeding system of Uvaria elmeri (Annonaceae) in a lowland mixed-dipterocarp forest in Sarawak. Am. J. Bot. 1997, 84, 208-213. [CrossRef]

60. Oliveira, P.E.; Gibbs, P.E. Reproductive biology of woody plants in a cerrado community of Central Brazil. Flora 2000, 195, 311-329. [CrossRef]

61. Caetano, A.P.S.; Cortez, P.A. Reprodução assexuada. In Biologia da Polinização; Rech, A.R., Agostini, K., Oliveira, P.E., Machado, I.C., Eds.; Projeto Cultural: Rio de Janeiro, Brazil, 2014; pp. 93-111.

62. Alves, R.M.; Artero, A.S.; Sebbenn, A.M.; Figueira, A. Mating system in a natural population of Theobroma grandiflorum (Willd. ex Spreng.) Schum., by microsatellite markers. Genet. Mol. Biol. 2003, 26, 373-379. [CrossRef]

63. Rech, A.R. Reproductive biology of Davilla kunthii A. St-Hil. (Dilleniaceae) in Central Amazonia. Acta Bot. Bras. 2011, 25, 487-496. [CrossRef]

64. Saraiva, L.C.; Cesar, O.; Monteiro, R. Breeding systems of shrubs and trees of a Brazilian savanna. Arq. Biol. Tecnol. 1996, 39, 751-763.

65. Ishara, K.L.; Maimoni-Rodella, C.S. Pollination and dispersal systems in a Cerrado remnant (Brazilian Savanna) in Southeastern Brazil. Braz. Arch. Biol. Technol. 2011, 54, 629-642. [CrossRef]

66. Gottsberger, G.; Silberbauer-Gottsberger, I. Pollination and floral biology in one hectare of Cerrado. In Life in the Cerrado: A South American Tropical Seasonal Vegetation; Reta Verlag: Ulm, Germany, 2006; Volume 2.

67. Barbosa, A.A.A. Biologia Reprodutiva de Uma Comunidade de Campo Sujo, Uberlândia/MG. Ph.D. Thesis, Universidade Estadual de Campinas, Campinas, Brazil, 1997.

68. Borges, H.B.N. Biologia Reprodutiva e Onservação do Estrato Lenhoso Numa Comunidade do Cerrado. Ph.D. Thesis, Universidade Estadual de Campinas, Campinas, Brazil, 2000.

69. Martins, F.Q.; Batalha, M.A. Pollination systems and floral traits in Cerrado woody species of the Upper Taquari Region (Central Brazil). Braz. J. Biol. 2006, 66, 543-552. [CrossRef] [PubMed]

70. Paulino-Neto, H.F. História Natural e Interação Flores-Besouros em Espécies de Cerrado. Ph.D. Thesis, Universidade de São Paulo, São Paulo, Brazil, 2009.

71. Batalha, M.A.; Mantovani, W. Reproductive phenological patterns of Cerrado plant species at the Pé-de-Gigante Reserve (Santa Rita do Passa Quatro, SP, Brasil): A comparison between the herbaceous and woody floras. Braz. J. Biol. 2000, 60, $129-145$.

72. Gottsberger, G. As anonáceas do cerrado e a sua polinização. Braz. J. Biol. 1994, 54, 391-402.

73. Riehs, P.J. Fenologia de algumas espécies do Gênero Cyclocephala (Coleoptera, Scarabaeidae) do este e centro-oeste do Paraná, Brasil. Rev. Ciênc. Exatas Nat. 2006, 8, 201-223.

74. Silva, N.A.P.; Frizzas, M.A.; Oliveira, C.M. Seasonality in insect abundance in the Cerrado of Goiás State, Brazil. Rev. Bras. Entomol. 2011, 55, 79-87. [CrossRef]

75. Hausmann, C.; Samietz, J.; Dorn, S. Visual orientation of overwintered Anthonomus pomorum (Coleoptera: Curculionidae). Environ. Entomol. 2004, 33, 1410-1415. [CrossRef]

76. Döring, D.F.; Skellern, M.; Watts, N.; Cook, S.M. Colour choice behaviour in the pollen beetle Meligethes aeneus (Coleoptera: Nitidulidae). Physiol. Entomol. 2012, 37, 360-368. [CrossRef]

77. Sharkey, C.R.; Fujimoto, M.S.; Lord, N.P.; Shin, S.; McKenna, D.; Suvorov, A.; Martin, G.J.; Bybee, S.M. Overcoming the loss of blue sensitivity through opsin duplication in the largest animal group, beetles. Sci. Rep. 2017, 7, 8. [CrossRef] [PubMed]

78. Martínez-Harms, J.; Vorobyev, M.; Schron, J.; Shmida, A.; Keasar, T.; Homberg, U.; Schmeling, F.; Menzel, R. Evidence of red sensitive photoreceptors in Pygopleurus israelitus (Glaphyridae: Coleoptera) and its implications for beetle pollination in the southeast Mediterranean. J. Comp. Physiol. A 2012, 198, 451-463. [CrossRef]

79. Warrant, E.; Dacke, M. Vision and visual navigation in nocturnal insects. Annu. Rev. Entomol. 2011, 56, 239-254. [CrossRef] [PubMed]

80. Teichert, H.; Dötterl, S.; Frame, D.; Kirejtshuk, A.; Gottsberger, G. A novel pollination mode, saprocantharophily, in Duguetia cadaverica (Annonaceae): A stinkhorn (Phallales) flower mimic. Flora 2012, 207, 522-529. [CrossRef]

81. Elias, M.A.S.; Franceschinelli, E.V.; Juen, L.; Borges, F.J.A.; Ferreira, G.M.; Carvalho, F.M.V. Reproductive success of Cardiopetalum calophyllum (Annonaceae) treelets in fragments of Brazilian savanna. J. Trop. Ecol. 2012, 28, 317-320. [CrossRef] 
82. Cline, A.R.; Kinnee, S.A. A new species of sap beetle (Coleoptera: Nitidulidae) from Baja California Sur, Mexico, with a review of the genus Lobiopa Erichson. Pan-Pac. Entomol. 2012, 88, 202-211. [CrossRef]

83. Jürgens, A.; Webber, A.C.; Gottsberger, G. Floral scent compounds of Amazonian Annonaceae species pollinated by small beetles and thrips. Phytochemistry 2000, 55, 551-558. [CrossRef]

84. Maia, A.C.D.; Schlindwein, C.; Navarro, D.M.A.F.; Gibernau, M. Pollination of Philodendron acutatum (Araceae) in the Atlantic Forest of northeastern Brazil: A single scarab beetle species guarantees high fruit set. Int. J. Plant Sci. 2010, 171, 740-748. [CrossRef]

85. Goodrich, K.R. Floral scent in Annonaceae. Bot. J. Linn. Soc. 2012, 169, 262-279. [CrossRef]

86. Tsukada, M.; Inui, M.; Suzaki, N. Do beetles prefer the odor of female-stage to male-stage flowers in Atemoya, a cantharophylous protogynous fruit tree (Annonaceae)? J. Entomol. Res. Soc. 2017, 19, 43-52.

87. Schatz, G.E. Some aspects of pollination biology in Central American forests. In Reproductive Ecology of Tropical Forest Plants; Bawa, K.S., Hadley, M., Eds.; UNESCO and The Parthenon Publishing Group: Paris, France, 1990; pp. 69-84.

88. Braun, M.; Gottsberger, G. Floral biology and breeding system of Anaxagorea dolichocarpa (Annonaceae), with observations on the interval between anthesis and fruit formation. Phyton 2011, 51, 315-327.

89. Habeck, D.H. Nitidulidae Latreille 1802. In American Beetles; Arnet, R.H., Thomas, M.C., Skelley, P.E., Frank, J.H., Eds.; CRC Press: Boca Ratón, FL, USA, 2002; Volume 2, pp. 311-315.

90. Almeida, E.B., Jr.; Collevatti, R.G.; Telles, M.P.C.; Chaves, L.J.; Neres, D.F.; Soares, T.N. Short-distance pollen dispersal in a protogynous Annonaceae tree species from the Brazilian Cerrado. Plant Syst. Evol. 2018, 304, 1091-1099.

91. Gibernau, M.; Barabé, D.; Labat, D. Flowering and pollination of Philodendron melinonii (Araceae) in French Guiana. Plant Biol. 2000, 2, 331-334. [CrossRef]

92. Gottsberger, G. Pollination of some species of Carludovicoideae and remarks on the origin and evolution of Cyclanthaceae. Bot. Jahrb. Syst. 1991, 113, 221-235.

93. Meeuse, B.J.D.; Raskin, I. Sexual reproduction in the arum lily family, with emphasis on thermogenicity. Sex. Plant Reprod. 1988, 1, 3-15. [CrossRef]

94. Seymour, R.S.; Schultze-Motel, P. Heat-producing flowers. Endeavour 1997, 21, 125-129. [CrossRef]

95. Dieringer, G.; Reyes-Castillo, P.; Lara, M.; Cabrera, R.L.; Loya, L. Endothermy and floral utilization of Cyclocephala caelestis (Coleoptera: Scarabaeoidea; Melolonthidae); a cloud forest endemic beetle. Acta Zool. Mex. 1998, 73, 145-153.

96. Seymour, R.S.; Schultze-Motel, P. Physiological temperature regulation by flowers of the sacred lotus. Philos. Trans. R. Soc. 1998, 353, 935-943. [CrossRef]

97. Seymour, R.S.; White, C.R.; Gibernau, M. Heat reward for insect pollinators. Nature 2003, 426, 243-244. [CrossRef]

98. Rands, S.A.; Whitney, H.M. Floral temperature and optimal foraging: Is heat a feasible floral reward for pollinators? PLoS ONE 2008, 3, e2007. [CrossRef] [PubMed]

99. Seymour, R.S.; White, C.R.; Gibernau, M. Endothermy of dynastine scarab beetles (Cyclocephala colasi) associated with pollination biology of a thermogenic arum lily (Philodendron solimoesense). J. Exp. Biol. 2009, 212, 2960-2968. [CrossRef]

100. Silva, C.A.; Domingues-Neta, A.M. Aspectos reprodutivos e visitantes florais de Duguetia marcgraviana Mart. (Annonaceae) na região sudoeste de Mato Grosso. Biotemas 2010, 23, 69-76.

101. Costa, M.S.; Silva, R.J.; Paulino-Neto, H.F.; Ferreira, M.J.B. Beetle pollination and flowering rhythm of Annona coriacea Mart. (Annonaceae) in Brazilian Cerrado: Behavioral features of its principal pollinators. PLoS ONE 2017, 12, e0171092.

102. Silva-Júnior, M.C. 100 Árvores do Cerrado—Guia de Campo; Rede de sementes do Cerrado: Brasília, Brazil, 2005.

103. Lorenzi, H. Árvores Brasileiras: Manual de Identificação e Cultivo de Plantas Arbóreas Nativas do Brasil; Instituto Plantarum: Nova Odessa, Brazil, 2009; Volume 1.

104. Cavalcante, T.R.M.; Naves, R.V.; Franceschinelli, R.V.; da Silva, R.P. Polinização e formação de frutos em araticum. Bragantia 2009, $68,13-21$. [CrossRef]

105. Gottsberger, G.; Webber, A.C. Nutritious tissue in petals of Annonaceae and its function in pollination by scarab beetles. Acta Bot. Bras. 2018, 32, 279-286. [CrossRef]

106. Gottsberger, G. Beetle pollination and flowering rhythm of Annona spp. (Annonaceae) in Brazil. Plant Syst. Evol. 1989, 167, 165-187. [CrossRef]

107. Aragão, D.S.; Costa, C.B.N.; Nascimento, V.T. Biologia floral, fenologia reprodutiva e polinização de Xylopia aromatica (Lam.) Mart. (Annonaceae) em uma área de Cerrado no oeste da Bahia. Paubrasilia 2019, 2, 17-26. [CrossRef]

108. Paulino-Neto, H.F. Polinização e biologia reprodutiva do araticum-liso (Annona coriacea Mart.: Annonaceae) em uma área de Cerrado paulista: Implicações para fruticultura. Rev. Bras. Frutic. 2014, 36, 132-140. [CrossRef]

109. Paulino-Neto, H.F. Biologia de Reprodução de Annonaceae em Matas do Brasil Central. Undergraduate Thesis, Universidade Federal de Uberlândia, Uberlândia, Brazil, 1999.

110. van Kleunen, M.; Nänni, I.; Donaldson, J.S.; Manning, J.C. The role of beetle marks and flower colour on visitation by Monkey Beetles (Hopliini) in the Greater Cape Floral Region, South Africa. Ann. Bot. 2007, 100, 1483-1489. [CrossRef]

111. Aquino, F.G.; Miranda, G.H.B. Consequências ambientais da fragmentação de habitats no Cerrado. In Cerrado-Ecologia e Flora; Sano, S.M., Almeida, S.P., Ribeiro, J.F., Eds.; Embrapa Informação Tecnológica: Brasília, Brazil, 2008; Volume 1, pp. $383-398$. 
112. Moore, M.R.; Cave, R.D.; Branham, M.A. Synopsis of the cyclocephaline scarab beetles (Coleoptera, Scarabaeidae, Dynastinae). Zookeys 2018, 745, 1-99. [CrossRef] [PubMed]

113. Cordeiro, M.C.R.; Pinto, A.C.Q.; Ramos, V.H.V. O Cultivo da Pinha, Fruta-do-Conde ou Ata no Brasil; Embrapa Cerrados: Planaltina, Brazil, 2000.

114. Lemos, E.E.P. A Produção de Anonáceas no Brasil. Rev. Bras. Frutic. 2014, 36, 77-85. [CrossRef]

115. Parizotto, D.R.; Grossi, P.C. Revisiting pollinating Cyclocephala scarab beetles (Coleoptera: Melolonthidae: Dynastinae) associated with the soursop (Annona muricata, Annonaceae). Neotrop. Entomol. 2019, 48, 415-421. [CrossRef] 